\title{
PENGARUH TINGKAT PERTUMBUHAN LABA, VARIABILITAS LABA, DAN DIVIDEND PAYOUT RATIO TERHADAP PRICE EARNING RATIO PADA PERUSAHAAN MANUFAKTUR DI PT. BURSA EFEK JAKARTA
}

\author{
Ni Nyoman Yulianthini \\ Universitas Pendidikan Ganesha \\ Singaraja, Indonesia \\ e-mail : yulianthini12@gmail.com
}

\begin{abstract}
Abstrak
Penilaian terhadap price earning ratio dapat digunakan sebagai dasar pengambilan keputusan yang lebih relevan dibandingkan pendekatan present value di pasar modal. Penelitian ini dimaksudkan untuk mengetahui pengaruh tingkat pertumbuhan laba, variabilitas laba dan dividend payout ratio terhadap dalam penelitian ini adalah regresi linier berganda. Berdasarkan pengujian secara serempak diperoleh hasil bahwa tingkat pertumbuhan laba, variabilitas laba dan dividend payout ratio secara simultan berpengaruh signifikan terhadap price earning ratio pada perusahaan manufaktur di PT. Bursa Efek Jakarta dengan taraf nyata 5 persen. Koefisien determinasi sebesar 63,8 persen, yang menunjukkan bahwa 63,8 persen variasi (naik turunnya) PER ditentukan oleh tingkat pertumbuhan laba, variabilitas laba dan dividend payout ratio dan sisanya sebesar 36,2 persen dipengaruhi variabel lain. Pengujian secara parsial menunjukkan bahwa tingkat pertumbuhan laba, variabilitas laba dan dividend payout ratio berpengaruh signifikan terhadap PER dengan taraf nyata 5 persen. Sedangkan variabel yang paling berpengaruh terhadap PER pada perusahaan manufaktur di di PT. Bursa Efek Jakarta adalah variabilitas laba dengan kontribusi sebesar 46,4 persen.
\end{abstract}

Kata kunci: Dividend Payout Ratio, Price Earning Ratio, Tingkat Pertumbuhan Laba, Variabilitas Laba

\begin{abstract}
Assessment of price earnings ratio can be used as a basis for decision making that is more relevant than the present value approach in the capital market. This study is intended to determine the effect of the level of profit growth, profit variability and dividend payout ratio in this study is multiple linear regression. Based on the simultaneous testing of the results obtained that the rate of profit growth, profit variability and dividend payout ratio simultaneously have a significant effect on price earnings ratio in manufacturing companies at PT. Jakarta Stock Exchange with a real level of 5 percent. Determination coefficient of 63.8 percent, which shows that 63.8 percent of the variation (rise and fall) of PER is determined by the rate of profit growth, profit variability and dividend payout ratio and the remaining 36.2 percent is influenced by other variables. Partial testing shows that the rate of profit growth, profit variability and dividend payout ratio have a significant effect on PER with a real level of 5 percent. While the most influential variable on PER in manufacturing companies at PT. The Jakarta Stock Exchange is profit variability with a contribution of 46.4 percent.
\end{abstract}

Keywords: Dividend Payout Ratio, Price Earning Ratio, Profit Growth Rate, Profit Variability 


\section{Pendahuluan}

Pasar modal banyak dijumpai pada banyak Negara, karena pasar modal menjalankan fungsi ekonomi dan keuangan. Menurut Sodikin (2016) Pasar modal memiliki peran penting dalam meningkatkan perekonomian suatu negara. Dengan adanya pasar modal, investor sebagai pihak yang memiliki kelebihan dana dapat menginvestasikan dananya dalam sekuritas yang ada di pasar modal dengan harapan akan mendapatkan keuntungan. Sedangkan bagi perusahaan sebagai pihak yang memerlukan dana dapat memanfaat dana tersebut untuk mengembangkan kegiatan aktivitas operasional perusahaan, sehingga dapat meningkatkan kegiatan perekonomian negara dan kesejahteraan masyarakat luas. Dalam melakukan investasi, penilaian adalah hal yang paling penting untuk dapat dijadikan dasar dalam pengambilan keputusan yang lebih rasional. Salah satu pendekatan yang umumnya dipakai oleh analis sekuritas yaitu pendekatan Price Earning Ratio (PER) yang merupakan perbandingan antara harga pasar suatu saham dengan laba per lembar saham / Earning Per Share (EPS). Menurut Asteria (2016) Price to Earnings Ratio (PER) merupakan salah satu rasio keuangan perusahaan yang dapat mempengaruhi harga saham lebih dominan dibanding Earning Per Share (EPS). Oleh karena itu dalam analisis mengenai pergerakan harga saham, pertimbangan tentang Price Earning Ratio (PER) sangat penting. Terlebih dalam jangka panjang, PER lebih volatile dibanding EPS. Ketidakstabilan PER disebabkan oleh adanya perubahan required rate of return $(\mathrm{k})$ dan gowth rate of dividend $(\mathrm{g})$, Semakin besar kepercayaan investor terhadap masa depan perusahaan. Tujuan dari analisis ini adalah untuk mengetahui bagaimana posisi suatu saham relatif terhadap saham-saham lain, dengan menggunakan variabel-variabel yang mempengaruhi PER. Menurut S. Yuniep Mujati (2016) Price Earning Ratio menunjukkan perbandingan harga saham yang dibeli dengan earning yang akan diperoleh dikemudian hari sehingga hal tersebut menunjukkan bahwa investor yakin terhadap besarnya earning yang diberikan perusahaan, yang nantinya akan dibagikan kepada pemegang saham dalam bentuk dividen dimasa datang. Price Earning Ratio menunjukkan pertumbuhan laba dari perusahaan, dan investor akan tertarik terhadap pertumbuhan laba tersebut sehingga pada akhirnya akan memberikan efek terhadap pergerakan harga saham. Menurut Suryanto (2016) PER merupakan variabel yang digunakan dalam estimasi nilai intrinsik saham yaitu dengan mengalikannya dengan Earning Per Share (EPS) yang diharapkan. EPS atau laba per saham adalah rasio yang mengukur pendapatan bersih perusahaan pada suatu periode dibagi dengan jumlah saham yang beredar. Ketika investor mengevaluasi performance dari perusahaan, investor tidak cukup hanya mengetahui apakah income suatu perusahaan mengalami kenaikan atau penurunan, investor juga perlu mencermati bagaimana perubahan income berakibat terhadap investasinya.

Menurut model Whitbeck-Kisor, yang dikutip Suad Husnan (1998:309) ada tiga variabel yang mempengaruhi PER, yaitu (1) tingkat pertumbuhan laba, (2) deviasi standar tingkat pertumbuhan / variabilitas laba , (3) dividend payout ratio. Tingkat pertumbuhan laba memiliki hubungan yang positif dengan PER, artinya semakin tinggi tingkat pertumbuhan laba, maka semakin besar PER-nya. Variabilitas laba memiliki hubungan yang negatif terhadap PER, artinya semakin tinggi variabilitas laba, maka PER-nya semakin kecil, dan dividend payout ratio memiliki hubungan yang positif terhadap PER, dimana semakin tinggi dividend payout ratio semakin besar pula PER-nya. Dengan membayar deviden berarti nilai dividend payout ratio dari emiten dapat ditentukan. Berdasarkan ICMD (Indonesian Capital Market Directory), dari 28 perusahaan yang membagikan deviden tiga kali berturut-turut kepada pemegang saham, hanya 8 perusahaan yang membagikan deviden dengan nilai PER yang meningkat, sedangkan perusahaan lainnya membagikan deviden dengan nilai yang berfluktuatif. 
Tabel 1. Perusahaan Manufaktur di PT Bursa Efek Jakarta

\begin{tabular}{|c|c|c|c|c|c|}
\hline No. & Nama Perusahaan & $\begin{array}{c}\text { PER } \\
(\mathrm{x})\end{array}$ & $\begin{array}{c}\text { Tk. } \\
\text { Pertb. } \\
\text { Laba } \\
(\%)\end{array}$ & $\begin{array}{l}\text { Var. } \\
\text { Laba } \\
\text { (x) }\end{array}$ & $\begin{array}{c}\text { DPR } \\
\text { (\%) }\end{array}$ \\
\hline 1 & PT Aqua Golden Misisipi Tbk & 4,79 & 115,49 & 0,78 & 17,11 \\
\hline 2 & PT BAT Indonesia Tbk & 13,9 & $-30,71$ & 22,22 & 40,2 \\
\hline 3 & PT Dancos Laboratories Tbk & 10,78 & $-35,44$ & 3,98 & 39,21 \\
\hline 4 & PT Delta Djakarta Tbk & 3,45 & $-39,68$ & 0,47 & 13,97 \\
\hline 5 & PT Duta Pertiwi Nusantara Tbk & 4,16 & $-45,88$ & 0,95 & 36,21 \\
\hline 6 & PT Ekadharma Tape Industries Tbk & 5,14 & $-50,90$ & 0,76 & 55,03 \\
\hline 7 & PT Eratex Djaja Ltd Tbk & 7,85 & $-62,76$ & 1,41 & 46,15 \\
\hline 8 & PT Fast Food Indonesia Tbk & 16,23 & $-78,47$ & 13,01 & 18,79 \\
\hline 9 & PT Goodyear Indonesia Tbk & 6,61 & $-57,77$ & 1,39 & 11,01 \\
\hline 10 & PT Gudang Garam Tbk & 11,15 & $-1,44$ & 2,11 & 42,89 \\
\hline 11 & PT Hanjaya Mandala Sampoerna Tbk & 68,19 & $-85,61$ & 39,96 & 160,17 \\
\hline 12 & PT Hexindo Adiperkasa Tbk & 2,52 & $-59,45$ & 0,37 & 0,11 \\
\hline 13 & PT Igar Jaya Tbk & 4,99 & $-92,73$ & 2,76 & 39,93 \\
\hline 14 & PT Indofood Sukses Makmur Tbk & 10,98 & $-90,68$ & 0,35 & 25,51 \\
\hline 15 & PT Intan Wijaya Internasional Tbk & 3,4 & 0,51 & 1,56 & 25,21 \\
\hline 16 & PT Lautan Luas Tbk & 12,15 & 0,00 & 8,90 & 20,99 \\
\hline 17 & PT Lion Metal Works Tbk & 2,44 & 60,54 & 2,60 & 79,67 \\
\hline 18 & PT Multi Bintang Indonesia Tbk & 7,64 & 50,37 & 4,16 & 18,37 \\
\hline 19 & PT Mustika Ratu Tbk & 4,59 & 49,24 & 5,01 & 51,04 \\
\hline 20 & PT Pan Brothers Tex Tbk & 6,67 & 3,17 & 1,06 & 17,95 \\
\hline 21 & PT Selamat Sempurna Tbk & 8,8 & 46,45 & 1,10 & 25,08 \\
\hline 22 & PT Sepatu Bata Tbk & 2,5 & 25,64 & 0,71 & 72,88 \\
\hline 23 & PT Supreme Cable Manufacturing Coorp. Tbk & 0,42 & 187,02 & 0,30 & 3,35 \\
\hline 24 & PT Tembaga Mulia Semanam Tbk & 6,99 & 49,03 & 3,94 & 20,72 \\
\hline 25 & PT Tirta Mahakam Plywood Industry Tbk & 9,22 & $-55,32$ & 10,94 & 30,34 \\
\hline 26 & PT Tempo Scan Pasific Tbk & 3,98 & 288,44 & 18,19 & 19,41 \\
\hline 27 & PT Tunas Ridean Tbk & 16,53 & $-26,09$ & 2,07 & 80,82 \\
\hline 28 & PT Unilever Indonesia Tbk & 11,73 & $-84,74$ & 3,34 & 64,74 \\
\hline
\end{tabular}

Sumber: Indonesian Capital Market Directory

Dengan mengetahui besarnya pengaruh dari faktor-faktor yang mempengaruhi PER sesuai dengan model Whitbeck-Kisor, maka dapat dijadikan informasi dan sumber referensi bagi perusahaan (emiten) sehingga menjadi dasar dalam pengambilan kebijaksanaan dalam operasional perusahaan. Oleh sebab itu dengan menganalisis faktor-faktor yang mempengaruhi PER dapat membantu dalam membuat keputusan yang lebih cepat.

\section{Metode}

Metode yang dipergunakan untuk menentukan sampel adalah purposive sampling yaitu pengambilan sampel yang tidak acak berdasarkan criteria-kriteria tertentu. Populasi yang digunakan adalah seluruh perusahaan manufaktur yang terdaftar di PT BEJ sebanyak 155 perusahaan. Dari jumlah tersebut terdapat 28 perusahaan yang membagikan deviden berturutturut selama 3 tahun, sehingga diperoleh jumlah sampel sebanyak 28 perusahaan. Metode pengumpulan data yang dipergunakan adalah metode observasi non prilaku, yaitu data dikumpulkan dengan cara mengamati, mencatat dan mempelajari buku yang berkaitan dengan 
penelitian seperti ICMD. Sedangkan teknik analisis data yang digunakan adalah Analisis Regresi Linier Berganda.

\section{Hasil dan Pembahasan}

Penelitian ini dimaksudkan untuk mengetahui baik secara simultan maupun parsial pengaruh tingkat pertumbuhan laba, variabilitas laba dan dividend payout ratio terhadap price earning ratio pada perusahaan manufaktur di PT BEJ, serta untuk mana yang paling berpengaruh terhadap price earning ratio.

Berdasarkan data pada laporan keuangan masing-masing perusahaan dan beberapa data yang telah diolah, dapat disajikan gambaran umum variabel penelitian (price earning ratio, tingkat pertumbuhan laba, variabilitas laba dan dividend payout ratio).

\section{Price Earning Ratio (Y)}

Perusahaan yang memiliki nilai PER tertinggi adalah PT. Hanjaya Mandala Sampoerna Tbk sebesar 68,19 kali. Sedangkan PER terendah adalah PT. Supreme Cable Manufacturing Coorp. Tbk sebesar 0,42 kali. Secara keseluruhan perusahaan yang diteliti tetap memperoleh keuntungan karena nilai PER-nya positif, sebaliknya jika PER-nya bernilai negatif, maka akan menunjukkan kerugian.

\section{Tingkat Pertumbuhan Laba $\left(\mathrm{X}_{1}\right)$}

Tingkat Tingkat pertumbuhan laba tertinggi adalah PT Tempo Scan Pasific Tbk sebesar $288,44 \%$ dan terendah dialami oleh PT Igar Jaya Tbk sebesar - 92,73\%. Hal ini berarti bahwa perusahaan yang memiliki tingkat pertumbuhan laba tertinggi mengalami keuntungan berlipat, sedangkan perusahaan yang memiliki tingkat pertumbuhan laba terendah mengalami kerugian yang cukup besar. Tingkat pertumbuhan laba memiliki hubungan yang searah dengan PER. Makin tinggi tingkat pertumbuhan laba akan meningkatkan nilai perusahaan di mata investor untuk membeli saham perusahaan tersebut, sehingga harga saham makin tinggi yang berarti PER juga mengalami kenaikan.

\section{Variabilitas Laba $\left(\mathrm{X}_{2}\right)$}

Perusahaan dengan variabilitas laba tertinggi adalah PT Hanjaya Mandala Sampoerna Tbk sebesar 39,96 kali, sedangkan perusahaan dengan variabilitas laba terendah adalah PT Unilever Indonesia Tbk sebesar 0,09 kali. Makin rendah variabilitas laba, maka nilai PER akan semakin tinggi, ini dikarenakan variabilitas laba (pengukur risiko) yang rendah menunjukkan tingkat pengembalian yang diharapkan investor juga rendah, yang berarti investor tidak terlalu mengharapkan laba yang tinggi karena adanya faktor risiko, terutama dampak akibat terjadinya krisis ekonomi di Indonesia yang berkepanjangan dan keadaan politik yang semakin memanas.

\section{Dividend Payout Ratio $\left(\mathrm{X}_{3}\right)$}

Perusahaan dengan dividend payout ratio (DPR) tertinggi adalah PT Hanjaya Mandala Sampoerna Tbk sebesar 160,17\%, sedangkan perusahaan yang memiliki DPR terendah adalah Hexindo Adi Perkasa Tbk sebesar 0,11\%. Hal ini disebabkan karena perusahaan tersebut membagikan dividennya lebih besar dari laba yang diperoleh. DPR dan PER mempunyai hubungan yang searah yang berarti bahwa semakin tinggi dividen yang dibagi (DPR) maka semakin banyak saham baru yang dikeluarkan dengan harga makin tinggi, selain itu investor cenderung akan membeli saham tersebut karena tertarik dengan tinggi dividen yang dibagikan yang mengakibatkan harga saham makin naik.

Analisis ini digunakan untuk mengetahui ada atau tidaknya pengaruh antara variabel bebas yaitu tingkat pertumbuhan laba $\left(\mathrm{X}_{1}\right)$, variabilitas laba $\left(\mathrm{X}_{2}\right)$ dan Dividend Payout Ratio $\left(\mathrm{X}_{3}\right)$ terhadap variabel terikat yaitu Price Earning Ratio pada perusahaan manufaktur di PT BEJ. Untuk mempermudah pengolahan data digunakan bantuan computer dengan menggunakan program SPSS versai 10.0. Adapun rangkuman hasil pengolahan datanya dapat dilihat pada 
Tabel 2. Dari hasil analisis pada tabel 4.1 dapat diperoleh persamaan garis linier berganda sebagai berikut:

$$
Y=1,845-0,02183 X_{1+} 0,695 X_{2}+0,09759 X_{3}
$$

Tabel 2. Rangkuman Hasil Analisis pada Perusahaan Manufaktur di BEJ

\begin{tabular}{lcccc}
\hline \multicolumn{1}{c}{ Nama Variabel } & $\begin{array}{c}\text { Koefisien } \\
\text { Regresi }\end{array}$ & t test & $\begin{array}{c}\text { Uji Parsial } \\
\text { Probabilitas }\end{array}$ & $\mathbf{r}^{2}$ Parsial \\
\hline $\mathrm{X}_{1} \quad$ Tk. Pertumbuhan Laba & $-0,02183$ & $-2,985$ & 0,004 & 0,085 \\
$\mathrm{X}_{2} \quad$ Variabilitas Laba & 0,695 & 8,568 & 0,000 & 0,464 \\
$\mathrm{X}_{3} \quad$ Dividend Payout Ratio & 0,09759 & 4,362 & 0,000 & 0,283 \\
Konstanta & $=1,845$ & & & \\
Koef.Korelasi Multiple $(\mathrm{R})$ & $=0,799$ & & & \\
Koef.Determinasi Multipl $\left(\mathrm{R}^{2}\right)$ & $=0,638$ & & & \\
F - Ratio & $=47,069$ & & & \\
Probabilitas & $=0,000$ & & & \\
\hline
\end{tabular}

Dimana:

$$
\begin{aligned}
& \mathrm{Y}=\text { Price Earning Ratio } \\
& \mathrm{X}_{1}=\text { Tingkat Pertumbuhan Laba } \\
& \mathrm{X}_{2}=\text { Variabilitas Laba } \\
& \mathrm{X}_{3}=\text { Dividend Payout Ratio (DPR) }
\end{aligned}
$$

Dari persamaan tersebut dapat diketahui bahwa bila tingkat pertumbuhan laba $\left(\mathrm{X}_{1}\right)$, variabilitas laba $\left(X_{2}\right)$ dan Dividend Payout Ratio $\left(X_{3}\right)$ sama dengan nol, maka nilai PER sebesar 1,845 kali. Bila dilihat dari koefisien tiap-tiap variabel dapat diartikan bahwa setiap peningkatan $1 \%$ tingkat pertumbuhan laba $\left(\mathrm{X}_{1}\right)$, maka PER akan turun sebesar 0,02183 kali dengan asumsi variabel lainnya konstan. Untuk kenaikan $1 \%$ variabilitas laba $\left(\mathrm{X}_{2}\right)$ dapat meningkatkan PER sebesar 0,695 kali dengan asumsi variabel lainnya konstan, sedangkan untuk peningkatan $1 \%$ dividend payout ratio $\left(X_{3}\right)$ dapat meningkatkan PER sebesar 0,09759 kali dengan asumsi variabel lainnya konstan. Koefesien regresi variabel bebas yang bertanda positif berarti mempunyai pengaruh yang searah terhadap PER demikian pula sebaliknya apabila negatif berarti memiliki pengaruh yang berlawanan terhadap PER. Selanjutnya untuk mengetahui apakah variabel bebas memiliki pengaruh signifikan atau tidak terhadap variabel terikat, maka dilakukan uji hipotesis secara simultan dan parsial.

\section{A. Pengaruh Tingkat Pertumbuhan Laba, Variabilitas Laba, dan Dividend Payout Ratio Secara Simultan terhadap PER}

Bila ditinjau dari uji statistiknya yaitu uji $F$ diperoleh probabilitas sebesar 0,000 (Tabel 2) yang lebih kecil dari $5 \%$, menunjukkan bahwa secara simultan (bersama-sama) tingkat pertumbuhan laba $\left(\mathrm{X}_{1}\right)$, variabilitas laba $\left(\mathrm{X}_{2}\right)$ dan Dividend Payout Ratio $\left(\mathrm{X}_{3}\right)$ berpengaruh signifikan terhadap PER. Besarnya koefisien determinasi 0,638 atau 63,8\% berarti bahwa tingkat pertumbuhan laba, variabilitas laba, dan DPR secara serempak mampu jelaskan variasi naik turunnya PER sebesar $63,8 \%$ dan sisanya sebesar $36,2 \%$ dipengaruhi oleh faktor lain yang tidak dapat dijelaskan dalam model. 


\section{B. Pengaruh Tingkat Pertumbuhan Laba, Variabilitas Laba, dan Dividend Payout Ratio Secara Parsial terhadap PER}

Ditinjau dari statistik ujinya yaitu uji $\mathrm{t}$ (Tabel 2) diketahui $\mathrm{t}$ hitung untuk tingkat pertumbuhan laba $\left(X_{1}\right.$ ) sebesar -2,985 dengan probabilitas 0,004 yang ternyata lebih kecil dari $5 \%$ yang berarti bahwa variasi tingkat pertumbuhan laba berpengaruh secara signifikan terhadap PER, besarnya kontribusi tersebut dapat dilihat dari $r^{2}$ yang besarnya 0,085 atau $8,5 \%$. Dari persamaan regresi tersebut berbeda dengan teori yang menyatakan bahwa tingkat pertumbuhan laba berpengaruh positif terhadap PER. Kemungkinan penyebabnya karena dampak krisis ekonomi yang berlarut-larut dan situasi politik yang kian memanas, sehingga pasar tidak lagi percaya pada informasi keuangan suatu perusahaan terutama mengenai laba yang diperoleh, sebagai akibatnya dapat menurunkan nilai perusahaan di mata investor.

Untuk variabilitas laba, t hitungnya sebesar 8,568 dengan probabilitas 0,000 yang lebih kecil dari $5 \%$ yang berarti variasi dari variabilitas laba berpengaruh secara signifikan terhadap PER, dimana besarnya kontribusi yang dilihat dari $r^{2}$ sebesar 0,464 atau $46,4 \%$. Dilihat dari persamaan regresi diketahui bahwa variabilitas laba mempunyai pengaruh yang positif terhadap PER. Ternyata hasil penelitian ini berbeda dengan teori, kemungkinan penyebabnya adalah walaupun investasi terhadap suatu saham perusahaan berisiko tinggi, tetapi investor masih mengharapkan keuntungan yang tinggi pula di masa yang akan datang.

Kemudian dilihat dari t hitung untuk variabel DPR diperoleh hasil sebesar 4,362 dengan probabilitas sebesar 0,000 yang ternyata lebih kecil dari $5 \%$, yang berarti bahwa variasi DPR berpengaruh secara signifikan terhadap PER dimana besarnya kontribusi dapat dilihat dari $r^{2}$ yaitu sebesar 0,283 atau $28,3 \%$. Ini berarti semakin banyak dividen yang dibagikan, maka akan berpengaruh kepada kenaikan harga saham yang pada akhirnya dapat meningkatkan harga saham. Dengan pembuktian ini dapat diketahui bahwa kenaikan maupun penurunan tingkat pertumbuhan laba $(8,5 \%)$, variabilitas laba $(46,4 \%)$, dan DPR $(28,3 \%)$ mempengaruhi PER secara parsial pada perusahaan manufaktur di PT BEJ.

\section{Pengaruh Variabel Dominan terhadap PER}

Dengan membandingkan besarnya kontribusi masing-masing variabel bebas $\left(r^{2}\right)$ diketahui bahwa variabilitas laba yang mempunyai kontribusi paling besar yaitu sebesar $46,4 \%$ jika dibandingkan dengan kontribusi tingkat pertumbuhan laba sebesar 8,5\% dan kontribusi DPR sebesar $28,3 \%$ terhadap PER. Hal ini disebabkan karena sebagian besar perusahaan membagikan dividen tidak terlalu besar, dengan tujuan menghindari berkurangnya laba yang diperoleh. Kemungkinan yang kedua yaitu situasi perekonomian Indonesia yang belum stabil sebagai akibat dari krisis ekonomi yang terjadi, sehingga investor lebih mempertimbangkan risiko yang dihadapi dari kegiatan investasinya.

\section{Simpulan dan Saran}

Berdasarkan uraian dari hasil pembahasan , dapat ditarik simpulan sebagai berikut: 1) Secara simultan (bersama-sama) tingkat pertumbuhan laba, variabilitas laba dan dividend payout ratio berpengaruh signifikan terhadap PER pada perusahaan manufaktur di PT BEJ yaitu sebesar $63,8 \%$. 2) Secara parsial tingkat pertumbuhan laba, variabilitas laba dan dividend payout ratio berpengaruh signifikan terhadap PER pada perusahaan manufaktur di PT BEJ, dengan pengaruh masing-masing sebesar 8,5\%, 46,4\% dan 28,3\%. 3) Secara parsial dapat dibuktikan bahwa variabilitas laba paling berpengaruh terhadap PER yaitu sebesar $46,4 \%$.

Berdasarkan simpulan diatas, maka dapat dikemukakan saran sebagai berikut: 1) Perusahaan yang termasuk sector manufaktur, hendaknya tetap harus memperhatikan kinerja keuangannya yang tercermin dalam variabel-variabel keuangan yang mempengaruhi PER sehingga dapat menjaga bahkan meningkatkan laba perusahaan antara lain dengan mengembangkan perusahaan secara internal yang mengharuskan pihak manajemen untuk 
menahan laba yang sebelumnya diperoleh dengan harapan tingkat hasil yang diberikan semakin besar dan harga saham umumnya akan meningkat. 2) Variabel keuangan yang sebaiknya lebih diperhatikan oleh emiten adalah variabilitas laba, karena variabel ini telah terbukti paling berpengaruh terhadap PER khususnya pada perusahaan manufaktur di PT. BEJ.

\section{Daftar Rujukan}

Agus Sartono. 2001. Manajemen Keuangan Teori dan Aplikasi. Edisi Keempat. Yogyakarta : BPFE.

Beta Asteria. 2016. Analisis Faktor-Faktor yang Mempengaruhi Price Earning Ratio pada Perusahaan LQ 45. Jurnal Riset Manajemen Vol. 3, No. 1, Hal. 49 - 60. Tersedia Pada: http://jurnal.stieww.ac.id/index.php/jrm/article/download/176/144/.

Institute For Economic and Financial Research. 2003. Indonesian Capital Market Directory. Jakarta : PT. BEJ.

Jogiyanto H.M. 2000. Teori Portofolio dan Analisis Investasi. Edisi Kedua. Yogyakarta: BPFE.

Kieso \& Weygandt. 1995. Akuntansi Intermediate, Herman Wibowo, Penerjemah. Edisi Ketujuh. Jakarta: Bina Rupa Aksara.

Nata Wirawan. 1998. Statistik 2 Inferensial Untuk Ekonomi dan Bisnis. Edisi Pertama. Denpasar: FE-UNUD.

Robert Ang, 1997. Buku Pintar Pasar Modal Indonesia. Edisi Pertama. Indonesia : Mediasoft Indonesia.

Sodikin, Suherman, Nurul Wuldanib. 2016. Pengaruh Price Earning Ratio (PER) dan Earning Per Share (EPS) terhadap Return Saham (Studi Pada PT. Unilever Indonesia Tbk.). Jurnal Ekonomi Manajemen Volume 2 Nomor 1 Hal. 18-25. Tersedia Pada: http://jurnal.unsil.ac.id/index.php/jem.

Suryanto. 2016. Stock Valuation By Using Price Earning Ratio (PER) In Stock Index LQ45. Jurnal AdBispreneur Vol. 1, No. 2, Hal. 137-144. Tersedia Pada: http://jurnal.unpad.ac.id/adbispreneur/article/view/10236.

Suad Husnan. 1998. Dasar-Dasar Teori Portofolio dan Analisis Sekuritas. Edisi Ketiga. Yogyakarta : UPP AMP YKPN.

Sunariyah. 2000. Pengantar Pengetahuan Pasar Modal. Edisi Kedua. Yogyakarta : UPP AMP YKPN

S. Yuniep Mujati. 2016. Pengaruh Earning Per Share dan Price Earning Ratio terhadap Debt to Equity Ratio dan Harga Saham pada Perusahaan Sektor Makanan dan Minuman di Bursa Efek Indonesia. Eksis Vol XI No 1 Hal. 102-123. Tersedia Pada: https://ejournal.stiedewantara.ac.id/index.php/001/article/view/36/27. 